\title{
EDUCATION AND SOCIAL TRANSITION: VOCATIONALISM, IDEOLOGY AND THE PROBLEMS OF DEVELOPMENT
}

\author{
RONALD G. SULTANA
}

\begin{abstract}
In the early 1970s the socialist government of Malta embarked on a reform of vocational education. This reform programme had two aims: first, to build up the country's industrial base; second, to bridge the gap between intellectual and manual labour, as advocated by Marx and other socialist thinkers. This article argues that Malta's failure to achieve the second goal holds important lessons for those who continue to advocate socialist ideas.
\end{abstract}

Zusammenfassung - Anfang der 70er Jahre reformierte die sozialistische Regierung Maltas das maltesische Berufsbildungssystem. Dieses Reformprogramm hatte zwei Ziele: erstens sollte die industrielle Basis des Landes ausgebaut und zweitens die schon von Marx und anderen sozialistischen Denkern befürwortete Schließung der Lücke zwischen intellektuellen und manuellen Arbeitskräften erreicht werden. Dieser Artikel argumentiert dahingehend, daß der mißglückte Versuch Maltas, das zweite Ziel zu erreichen, eine wichtige Lektion für andere Befürworter sozialistischer Ideen sein kann.

Résumé - Au début des années 70, le gouvemement socialiste de Malte entreprit de réformer l'enseignement professionnel, afin d'atteindre deux objectifs: affermir les bases industrielles du pays et d'autre part combler le fossé entre travail manuel et travail intellectuel, comme le préconisaient Marx et d'autres penseurs socialistes. L'auteur soutient que l'échec de Malte dans la réalisation de ce dernier but contient une leçon importante pour ceux qui persistent à défendre les idées socialistes.

Sumario - En los primeros años de la década de los 70 , el gobierno socialista de Malta emprendió una reforma de la educación vocacional. El programa de reforma tenía dos objetivos: el primero era crear la base industrial del país; el segundo, salvar la distancia entre el trabajo manual e intelectual, tal como lo habían propuesto Marx y otros pensadores socialistas. El artículo sostiene que el intento fallido de Malta en lograr el segundo objetivo contiene enseñanzas para los que siguen defendiendo ideas socialistas.

Резуме - В начале 1970-х годов социалистическое правительство Мальты приступило к реформе профессионального образования. Эта программа реформ имела две цели: во-первых, создать промышленную базу страны; во-вторых, уменьшить пропасть между интеллектуальным и физическим трудом, как это провозглашалось Марксом и другими мыслителями-содиалистами. В статье утверждается, что неудачи Мальты в достижении этих делей несет в себе уроки для тех, кто продолжает проповедовать социалистические идеи.

International Review of Education - Internationale Zeitschrift für Erziehungswissenschaft Revue Internationale de l'Education 41(3-4): 199-221, 1995.

(c) 1995 Kluwer Academic Publishers. Printed in the Netherlands. 
The purpose of this article is to examine the extent to which vocational schools at the secondary school level, set up by a socialist government in Malta in 1972, have in fact lived up to the ideological claims made on their behalf. This evaluative exercise draws on a large data bank collected within a "Trade School Research Project" (TSRP) which the author directed between 1988 and 1992. Quantitative and qualitative research methods used included a detailed questionnaire (TSRPQ) with 680 15-year-old (male and female) trade school students, three tracer studies with 258 ex-students (male), ${ }^{1}$ in-depth interviews with 241 students and 137 teachers and instructors (of both sexes), and 60 industrialists. More than 800 hours of classroom and staffroom observation were spent in trade schools. ${ }^{2}$ Other forms of documentary evidence were culled from newspapers, and files in the Department of Education archives.

Before reporting the results of that evaluative exercise, it is first of all necessary to outline the economic and ideological context which characterized Malta's social formation seven years after political independence from Britain in 1964.

\section{The context}

The Malta Labour Party wrested government from a centre-right, conservative Nationalist Party in 1971, and this political change ushered in reforms in almost every aspect of Malta's social fabric, including education (Zammit 1984). As the 1973-1980 economic plan (Office of the Prime Minister 1973) pointed out, the main challenge facing the Islands was the development of economic independence, the diversification of a hitherto fortress economy, and the concomitant target of creating enough jobs to absorb all workers in the British Defence Sector. The dimensions of that challenge become clear when one realises that in 1972 there were already 6,000 unemployed out of a total pool of labour counting just over 100,000 persons. (The two islands of Malta and Gozo have populations of 325,000 and 25,000, respectively.) In addition to that, the "run-down" of the British military base, scheduled to reach its final phase in 1979, represented a loss of about 7,500 jobs. It was predicted that the numbers of unemployed would swell to 19,000 by the end of 1972 (Sunday Times of Malta 9/1/72: 16), ${ }^{3}$ while others calculated that the loss of the British services would affect local private enterprise, including night-clubs, the building industry and other private trade. "Imagine", said one correspondent, "23,000 jobless, and the chain reaction will start" (Times of Malta 20/1/72: 10).

While the economy was eventually to fare better than most thought it would, 1970-1974 was particularly challenging not only because of the loss of jobs with the British, but because the international energy crisis and unprecedented inflationary pressures exacerbated the situation (Briguglio 1988: 192). The Government had to resort to the creation of emergency labour 
corps which soaked up as many as 7,810 persons in 1976 (Reports of the Working of Government Departments 1975-76: 96), and to Malta's traditional solution to economic crises, emigration. 3,585 left the islands in 1973 (RWGD 1972-73: 127), but the world recession meant that more and more countries imposed restrictions on the influx of migrants.

Malta's attempts to attract foreign investment, started in the post-war period and reinvigorated since the independence of the islands in 1964 were, by and large, successful in establishing a small manufacturing base. From just $17 \%$ in the early sixties, this increased to about $33 \%$ during the late seventies (Briguglio 1988: 193). However, the government's strategy to attract labour intensive industries to Malta carried with it the promise of cheap labour, together with differential wages for males and females, which meant that the latter rather than the former moved into the new manufacturing sectors in the clothing, textile, and electrical machinery industries (Darmanin 1992: 108-111). Opportunities for women in semi- and unskilled labour induced more women to work, and indeed female employment as a percentage of total gainful employment increased from just over $18 \%$ in the early sixties to about $26 \%$ in the late seventies (Briguglio 1988: 195).

\section{Ideology, education and the dependent state}

It was in the face of critical economic difficulties, therefore, that the Labour Party attempted to introduce socialist forms of production and relations in Malta. The state of dependency and underdevelopment imposed severe restrictions on this project, however, and led to a number of contradictory settlements. On the one hand, foreign investors had to be wooed, one of the key lures being the provision of a cheap labour pool. On the other hand, the Labour Party's socialist platform implied the privileging of the manual labouring classes.

Socialist ideology was clearly and specifically articulated by the Mintoffled Labour government, even though the Prime Minister did not, "in practice ... allow ideology to impede economic progress" (Zammit 1984: 58-9). A key goal of the 1973-1980 Development Plan was the promotion and greater awareness of manual labour's dignity, status and potential contribution to society (Office of the Prime Minister 1973: 74-5). Furthermore, work, rather than property ownership, was to be the foundation of the Republic, as expressed in the new Constitution of 1974 (Department of Information 1974). A number of banking and business concerns were nationalized, an extensive social welfare system established, and attempts were made to "promote new social bases of authority relations by simultaneously attacking the existing power centres and exposing them to public scrutiny or even ridicule" (Zammit 1984: 62). However, these changes in attitude would only come about if there was no longer "a wide disparity between a carpenter and a lawyer" (Parliamentary debates of 24/7/74, quoted in Zammit 1984: 64). By 1978 wage 
differentials were actually reduced from 15 times to only five times that of the lowest income (Farrugia 1979).

These and other elements of socialist ideology and practice were sustained in the educational field. By October 1972 the government announced its intention to restructure the educational system through the adoption of a seven year educational plan which would be closely synchronized with the economic plan for 1973-1980. The Minister of Education, Agatha Barbara, highlighted the ideological elements in the reform plan, saying that the new system would operate "to provide everybody with the same opportunities in education; to improve the status of manual workers, at the same time increasing the personal competence of the individual and his ${ }^{4}$ awareness of his contribution towards the country's development; to foster encouragement so that Malta attains economic independence; to alter the Maltese educational system from one based on the English system to one designed to meet Malta's needs and at the same time compatible with the system obtaining in Western Europe; to nurture among the Maltese and Gozitans freedom of thought and a sense of responsibility of the individual" (Times of Malta 12/12/72: 2). Irrespective of their abilities, all students would be exposed to a common curriculum until at least the second year of secondary schooling. In this way, the anti-social discrimination between students introduced into the secondary school system by the previous government in 1970, and based on the British tripartite model, would be discontinued. Remedial work with students who found difficulty in learning would ensure that every child would be a school achiever. Private schools, while not being abolished, would no longer be subsidized and helped in the same manner as before, as the elitism of some of these establishments contradicted the general commitment against selection underpinning the reforms. The university would no longer simply cater for those entering the professions, but positive discrimination would be implemented to encourage working class students to gain access as well.

The emphasis on "offering to all children the opportunity to develop to the best of their ability" (L-Orizzont 29/5/72: 7) had, however, to be linked to the need "to build a new Malta, with an independent economy, based on industrial development, with a full and wise use of its manpower potential" (L-Orizzont 29/5/72: 7). The Labour Party, traditionally keen to establish technical schools on the island (calls for the setting up of technical schools were made in the very first political manifesto of the MLP in 1921), and influenced by Thomas Balogh in favour of human capital theory (Balogh and Seers 1955; Sultana 1992a), wanted to extend the innovations made by the Nationalist government (Many of these, such as the setting up of secondary technical schools, were considered to be "technical in name only". L-Orizzont 29/5/72: 8), thus hoping to foster adequate industrial skills in the school system (Office of the Prime Minister 1973). Learning and education were to have "a utilitarian and cultural aim", for "educational instruction is primarily given so that man could contribute, by means of his work, towards the well-being of the 
state, of his family, and of himself" (MLP and General Workers Union's joint electoral programme 1976).

The Labour Party's belief in human capital theory, and the subsequent technification of secondary and tertiary education, brought it into confrontation with the growth of an ideology of individualism that was being celebrated world-wide in the 'sixties, and which, as Benavot (1983) has argued in a different context, eventually led to the demise of vocationalism at the compulsory school level. The Malta Union of Teachers (1968), the Graduate Teachers' Association (1970), and the Nationalist Party (Parliamentary Debates, Session No. 76, 23/5/72: 2290) had expressed an opposition to strict divisions between groups of students taking general and vocational courses after the second year at the secondary school level, all arguing that selection and specialisation should be left as late as possible in a student's educational career. Within this liberal discourse, the self-fulfillment of individuals had to take precedence over the economic "needs" of the country.

The Labour Party's position was quite the contrary. As Prime Minister Dom Mintoff frequently argued, individual ambitions and interests "matter little ... : one must first look at the country's needs" (Parliamentary Debates, March 1980). Economic imperatives demanded not only an extension and consolidation of technical institutes catering for those in post-compulsory education, but the introduction of trade schools at 13+ (Time of Malta 12/2/72: 11). These new schools would have $75 \%$ of their curriculum dedicated to vocational skills training, and $25 \%$ to traditional academic lessons. Only in this way would "the demand for technical workers and tradesmen which the industrial expansion of our country is aiming for" be met (Education Minister, quoted in L-Orizzont 29/5/72: 8). ${ }^{5}$

The shadow minister of education accused the Labour Party of throwing ideology to the wind, for such trade schools could only emphasize and deepen the class divide rather than level it (Parliamentary Debates 23/5/72: 2290 ff.). Indeed, the historical lineage of vocationalism suggests that capitalists' interest are served by trade schools, since these ensure the availability of a ready pool of docile and disciplined semi-skilled labourers with low aspirations and equally low expectations in terms of wages and working conditions (Kantor 1986). Aside from the fact that such schools have not proved to be as functional to capitalists as presumed (Sultana 1993), one could perhaps argue that the whole "transitional" context in which these schools were to operate in Malta was different. As has been noted above, the Labour Party was bent on introducing state capitalism, and surplus value was to be channelled to the social rather than the private sphere. A context which privileged manual labour, where active measures were being taken to break down social structuration, could make the trade schools similar to the Marxist-inspired "polytechnical schools" described below, thus serving not only economic interests, but simultaneously extending social transformation to the educational field. 


\section{Ideological aims of the trade schools}

The following sections address the ideological work of trade school, with particular reference to the declared goals of the Labour government in its vision for an education which would:

- conscientize, and hence serve the interests of the working class,

- privilege the manual and link it with the mind, and

- promote social mixing and educational equity.

A particular emphasis is placed on the "theoretical ideology" of work represented by teachers to trade school students, and on the "practical", "lived" ideology of work within these schools (Apple 1990). The former explores the relatively superficial, but nonetheless important overt curriculum, the latter the more influential, if covert, implicit curriculum of work. In examining the three assumptions above, the article makes an ongoing comparative analysis with experiments in vocational schooling in developing and developed countries.

Does vocational education conscientize, and hence serve the interests of the working class?

One definition of education stresses the role of schools and teachers in providing students with information and skills to decode the world in which they live, thus empowering them to assume a greater autonomy and control over their own lives. This process of "conscientization" (Freire 1972) leads students to understand - and work towards - their best interests within a framework where personal development promotes social equality and justice (Bowles and Gintis 1988: 236). Of the many aspects of the formal and informal curriculum, the most relevant in this context are the numerous studies which have analysed the ideological representations made to students and which purport to explain and define one's relationship to the sphere of production (Anyon 1981; Shilling 1989; Sultana 1990). For these messages are about that site where power relations in their economic form - commonly referred to as class relations - are played out, and where other power relationships based on gender and race, as well as age, come together to heavily influence a person's experience of life.

The research data available on school-to-work programmes point to the overwhelming conclusion that the principles, ideas and categories legitimated and conveyed by and within the schools represent particular visions of economic, racial and sexual realities and particular principles of social justice, with teachers involved in teaching for rather than about work (Simon et al. 1991). Schools therefore generally function to reproduce the social order by responding to the industrial imperative (Carnoy and Levin 1985), rather than transform it by responding to the democratic imperative so that "person rights" rather than "property rights" (Bowles and Gintis 1981) prevail. 
Teachers, both because of their class extraction and those cultural processes specific to the labour setting in which they participate (Sultana 1991a), have been generally reported to represent the industrial rather than the democratic imperative through the knowledge forms and content, and classroom social relations they transmit and encourage in schools. Within their structures and curricula, overtly and covertly, schools generally inculcate those qualities appreciated by employers, developing social relations that are authoritatively hierarchical, and thus promoting passivity, docility and silence.

Research has also noted the correspondence between the process of work and the role of workers and that of study and the role of students (Bowles and Gintis 1976; Anyon 1981; da Silva 1988). The latter are generally involved in tasks which have only an extrinsic validity; just as people work hard in order to earn a living, so do students "learn" in order to ensure access to a job. Like workers, students are rarely encouraged to participate actively, creatively and critically in the work/learning process, so that knowledge consumption rather than production is encouraged. This often results in an ethos of competition between students and in passivity towards authority, and produces an ideology inasmuch as it provides an effective guide to social practice within capitalist society.

Research from a variety of countries has shown that most of the ideas communicated by teachers about work are idealized, with work presented either as a self-fulfilling activity (with examples drawn from the professional careers) or as drudgery (factory work). Teachers tend to avoid controversial issues such as the role of trade unions or the problems of workers arising from their age, class, gender and/or race. Overt messages given by teachers are predominantly of the type that urge students to fit into and perform in the world of work as it is, rather than to explore its nature. Generally speaking, the organization of the forces of production is presented in an historical, reified manner, with employers being promoted uncritically as rightfully placed in positions of power deserving not only the surplus value of workers' labour, but also their respect, obedience and co-operation. Both covertly - through the inculcation of a competitive ethos and values of abdication and self-denial - and overtly students are taught to put employers' needs above their own, or to see them as complementary rather than conflicting. Workers are generally presented as involving themselves in competition for better places in the social order rather than voicing a unified concern for their own rights and dignity.

The hierarchical arrangement of labour is presented as a reality which is hardly ever subject to critical analysis, as are the differential status and rewards given to different workers. Students are therefore often invited by teachers to take their place in the occupational hierarchy, but little or no light is shed on the influence of class, race and gender in determining specific locations on the ladder, and the results of that location for their future lives. Rather, teachers have often been observed participating in defining the "realistic" and the "appropriate" for particular students. The only explanations offered to individuals for their reduced life chances and lower positions in the wider social 
structure are that they had not striven hard enough to deserve better. In this way, students participate in confirming their "destiny" by accepting personal responsibility for system-caused injustices. This is especially true for those institutions and programmes which, like trade schools, are directed mainly towards low-achieving, de-motivated students who have an overwhelmingly working class extraction (Watkins 1980; Sultana 1989).

Ethnographic research has shown that, despite the overwhelmingly hegemonic tenor of their messages, teachers and schools are also occasionally involved in individual and collective attempts to promote "person rights". Schools, and individual teachers within them, have a certain degree of autonomy because "the educational system is not an instrument of the capitalist class. It is the product of conflict between the dominant and the dominated. It is an area of conflict over the production of knowledge, ideology, and employment, a place where social movements try to meet their needs and business attempts to reproduce its hegemony" (Carnoy and Levin 1985: 50). That autonomy is occasionally used to help students critically engage with the world of work not merely to describe it - and fit into it - as it is, but rather to imagine and strive for a world as it could and should be (Sultana 1990; Simon et al. 1991).

It is appropriate to now consider the above in the Maltese context. Given that educational reform in Malta was launched on an ideological platform which highlighted the emancipation of the working class, one might assume that local evidence on the explicit and hidden curricula in trade schools would run counter to that found in other countries, where the emphasis is on the maintenance of the status quo. But if one looks at both the early stages of the vocational schools and at their recent history, the overwhelming conclusion is that not much in the way of "conscientization" took place, or is taking place in these educational spaces. Files held in the Department of Education archives indicate that there was a suggestion by a member of the Vocational Schools Committee to introduce the notion of co-operatives in the syllabus, and to have students involved in productive work on a co-operative basis. But this was a solitary instance, and no concrete measures were made to implement the proposal. Neither documents in the departmental files, nor oral evidence collected from pioneering teaching staff have at any stage hinted that trade schools were ever utilised to encourage critical consciousness among students, or to arm them with an alternative vision of industrial labour where they would be leaders rather than followers. In other words, the explicit ideology heralding the educational reforms was not followed up by innovatory curricular and pedagogical practices in trade schools, where ultimately, dilution of the "strong discourse" (Grignon 1971) of the academic school, rather than a creative challenge to it, took place. If anything, the trade schools served to dissuade students from investing in academic schooling, thus "ensuring" the availability of a pool of semi-skilled labourers willing to work for the cheap wages which attracted foreign industrial entrepreneurs to the islands.

Recent ethnographic evidence collected by members of the TSRP team 
(Mifud and Mallia $1991^{6}$ and Azzopardi and Bondin 19917) has confirmed that both the hidden and the explicit curricula in trade schools are overwhelmingly hegemonic. Both boys' and girls' schools encourage a belief in meritocracy, and in a liberal notion of choice which does not explain how systemic processes channel groups of students, identifiable by their class and gender background, to unrewarding segments of the labour market. The transmission of knowledge is marked by a bifurcation between work, which is generally tedious, repetitive and gives little opportunity for self-expression, and leisure, where one can literally "re-create" oneself. Teaching staff, even when these had become conscientized about industrial relations since they themselves had come up from the shop floor and experienced productive labour, generally implicitly and explicitly justified the hierarchical division of labour:

Teacher: There are two truths about work ... workers must receive their due in wages because everybody must eat . . . but God forbid that everybody would be paid equally! (Mifsud and Mallia 1991: 52).

Teachers also generally presented the employers' needs as sacrosanct, and often urged a sense of discipline on students because "In the factories where they're going to work, they're not going to let them eat all the time. So we train them not to eat; they eat only during breaks, and they gradually realise we're right. This is especially true of the girl who comes to visit us after finding a job in a factory, and tells her classmates how she's not even allowed to go to the toilets, or that they even time how long she spends in the loo. They start realising that what we're telling them is for their own good, so that they won't find it too difficult to adapt. We're training them right now for that" (Azzopardi and Bondin 1991: 156).

When asked which qualities schools and teachers promoted in view of the work place, students unhesitatingly replied that these were "That you do as told, that you obey and that you behave and not answer back, and things like that" (Mifsud and Mallia 1991: 58). In one religious instruction lesson, for instance, the teacher admonished her students (Mifsud and Mallia 1991: 95).

Teacher: Look, I'm treating you as friends. Do not answer back when a teacher confronts you. One day, that self-discipline will come in handy. Perhaps he's in the wrong, and he isn't right. But one day, your employer might harass you, and you aren't always in a position to stand up to him and leave.

Student. I'd shove my fist in his face!

Teacher: You'll have to put up with it, because you'll have a family.

Student. How long do you put up with it? One month? Two?

Teacher: More.

Student. Six months?

Teacher: Christ put up with it till he died.

Indeed, Mifsud and Mallia (1991) report that the few counter-hegemonic messages recorded were present almost exclusively in the "academic" schools, 
where historical perspectives on work, capitalism as one mode of production among others, the profit motive, the idea of waged labour, and gender inequalities in the Maltese labour market were addressed in a critical manner. The relaxation of the hierarchical classification between teachers and students was more in evidence in trade schools, though this had unintended - and ultimately hegemonic - consequences in so far as it led to a dilution of curricula and the further exclusion of students from knowledge (Claus 1990; Sultana 1992b).

\section{Does vocational education privilege the hand and link it with the mind?}

Various progressive educational theorists have favoured vocational forms of schooling, thinking that this "learning by doing" approach would link conception with the execution of tasks. Perhaps few have been more influential than John Dewey in the development of such a pedagogy. Dewey was part of a general reform movement in early twentieth-century America which took traditional schooling to task for being too bookish, unrelated to the real-life concerns of children, and out of touch with current technological developments which were not reflected in the curriculum. However, Dewey differed fundamentally from those contemporaries who, like David Snedden and Charles Prosser, Commissioner of Education and Executive Secretary of the National Society for the Promotion of Industrial Education respectively, believed uncritically in the emergence of scientific-corporate capitalism as the cosmic instrument of progress, and considered their task as "educators" to be one of lubricating the wheels of that giant machine. Within their socialDarwinist point of view, schooling was to be differentiated, with practical trade schooling for the offspring of the masses where ethos, curriculum and teacher-student relationships were to imitate the industrial shop-floor as closely as possible so that habits of "correct" thinking and doing would be established (Wirth 1988). Aspects of the liberal curriculum were to be taught in a practical manner, or not at all, to those attending these new schools.

This was inadmissable to Dewey, who argued that "a separation of trade education and general education of youth has the inevitable tendency to make both kinds of training narrower and less significant than the schooling in which the traditional education is reorganized to utilize the subject matter - active, scientific, and social of the present day environment" (Dewey 1915, quoted by Wirth 1988). Thus, Dewey distanced himself from the idea of a differentiated schooling - namely vocationalism for future labourers - to argue that the intellectual qualities necessary for sustaining democratic values were to be made available to all. Among the most important qualities was the ability to understand the new culture of technology and science, which held so much promise but also posed so many threats to democratic forms of life. It was for this reason that Dewey placed occupations at the heart of the programme of his Laboratory School. Vocational tasks, such as weaving wool into clothing, cooking, constructing and gardening, were not intended to be, as in 
the Snedden-Prosser plan, a schooling for work but rather an education about work. The "learning by doing" led children from doing to reflecting upon the doing, so that they would practice the scientific mode of inquiry by hypothesizing, reporting and testing in a rational and open community of learners, and in addition to consider, from a normative point of view, the way science and technology were being used to further or to dismantle democracy.

Dewey's agenda, combining mental and manual activity in an educational project which encouraged students to engage critically with an alienating capitalist world of work, caught the attention of Russian educators who were attempting to develop a schooling system and pedagogy which was ideologically in tune with the economic and political vision of the Revolution. It is no wonder, therefore, that N. K. Krupskaya, Lenin's wife, invited Dewey to the USSR to help in that endeavour, or that Dewey was attracted by the Russian experiments in "polytechnic education" (Morrison 1989). The latter approach to education was founded on the critique Marx had made of the division between intellectual and manual labour, and of the concomitant division between the twa major classes in society whereby the exercise of the brain was the key preserve of the bourgeoisie, and the use of brawn that of the proletariat. This was considered to be the main characteristic of the capitalist division of labour, where the separation between the conception and execution of a production process was the major cause of human alienation, and was reflected in a schooling system which reinforced those same characteristics. Modern industry, with its advanced division of labour, reduced persons to a mere fragment, stunting the development of qualities that are intrinsic to their species (Marx 1967: 488). The education of the future would be integrated with the transformed productive process in a socialist economy, and such an education would produce fully rounded personalities who would be able to theorize as well as work (Marx 1967: 528-550).

In his formulation of education, Marx was influenced by the craft schools which developed in France after the revolution of 1848, and especially by the writing of such radical writers as C. A. Corbon (Corbon 1859; Mjelde 1987). Marx held that a true education addressed the person in his and her totality, and therefore engaged the mind and the body hence his emphasis on gymnastics, military exercise and technology. Through the latter the child would learn the general principles of all processes of production and at the same time learn how to handle the elementary instruments of all trades (Ornelas 1981: 50). Such a "polytechnical education" would meet the specific needs of the working class and further its interests in relation to other classes, not particularly because it offered a better form of vocational training or because it inculcated a work ethic, but because it led to the development of a "whole human being", a "many-dimensional person" through the reconciliation of the historical gap between mental and manual, conception and execution. The conception of "polytechnic education" is therefore radically different from vocational school systems where the main intention is to provide skilled "hands". The capitalist is in favour of the latter, but they are "not in 
the least interested in having the workers either develop understanding of the need of their industry or acquire the skills necessary to manage production themselves - the management of production was the affairs of the factory owners, while the task of workers was to ensure that they did the work for the plant well" (Krupskaya 1985, quoted in Mjelde 1987: 12-13).

These ideas were used as guiding principles in the Soviet Union and Eastern European countries, with many school systems building a direct link between school and work through the polytechnical principle. Schools thus had links with factories or farm collectives, and students took part in production, with income from the sales of students' products meeting part of the costs of the technological schools. Krupskaya's polytechnical schools which set out "not only to give knowledge but to teach how to apply it to life" (Price 1977: 185 ) and Mao's reform of schools in line with the principles of the Cultural Revolution for the decade after 1966 where students experienced both intellectual and manual labour to help bridge and appreciate the value and importance of both (Tse Tung 1964: 295-309), were two attempts to apply Marx' insights in a non-capitalist context, while the educational systems feeding the producer cooperatives of Mondragon in Spain are probably the only successful experiment of this type in the West (Ornelas 1981).

Various countries "in transition" to one form or other of socialism have been inspired by Marx and his notion of polytechnic education, and set about placing a considerable emphasis on bridging the gap between mental and manual work. Some, such as Cuba, Mozambique and Tanzania, introduced a manual component at both the primary and the secondary school level. The purpose of this was largely ideological: "Since the traditional separation between the working class and the bourgeoisie in conditioned capitalist societies is between manual and mental work, the incorporation of the collectivized individual into the new people-nation requires breaking down these previous classifications" (Carnoy 1990: 72-3). The action within the school to remove traditional barriers and practices reflected economic policies towards an equalization of incomes and life-chances through wage policy agreements where the minimum wage was generally set at a ratio of 1:4 or 1:5 to the salary of a manager or professional, and by extending social services in areas such as health and housing (Carnoy 1990: 73). While in capitalist societies academic education is distinct from vocational education "as if it served a different purpose rather than simply supplying different kinds of knowledge and access to social/material status" to different youths from different social class backgrounds, transition societies define all education as vocational, "and the state attempts to minimize material and status differences among vocations" (Carnoy 1990: 90).

Transition societies attempted to bring about this change not only through legislation, but also through promoting a practical and lived ideology in various social sites. In schools, for instance, the formal curriculum as represented by lessons and textbooks, was used to transmit overt messages about the value of manual labour. In addition to that and perhaps more importantly, 
the hidden curriculum, as represented by the rituals, pedagogy and practices in schools, the social class clientele catered for, the activities and games played, and so on, socialised students into a different form of life, encouraging the embracing of values such as co-operation and equity, identified by the state as being more functional to the overall national ideal encapsulated by the word "socialism".

A review of the literature on experiments that set out to introduce vocational subjects in the curriculum in the hope that this would change students' attitudes towards manual labour shows, however, that many of these attempts failed (Psacharopoulos 1987). Class differences have proved to be much harder to eradicate than imagined, and consequently, despite the reduction of ideological and material differences among occupations and types of schooling, most people realise that the best opportunities are still available for those who are high achievers in the academic, formal and traditional school system. Thus, the best vocational education in transition societies "continues to be academic education, even though those students who are interested in more manual occupations do not pay nearly as high a material and status price for such tastes or talent as in conditioned capitalist societies" (Carnoy 1990: 90).

To turn again to the Maltese context: In some ways, the Malta Labour Party's goals for vocational schools fell within the ideological terrain charted by Marxism and socialism as understood in transition societies. As shown in the introduction to this article, these aims represented an attempt to privilege manual labour and to bridge the gap between hand and mind, and between the different social classes. The Labour Party leader, Dom Mintoff, visited China several times from 1972 onwards, and the educational thoughts of Mao, and later of Nyerere in Tanzania, must have connected with the Prime Minister's ideological persuasions and given these organizational substance. Reforms at the primary, secondary and tertiary education level in the 1970s included not only progressive policies adopted by most left-wing Western democracies since the late 1950s, such as the removal of streaming, and the introduction of comprehensives, but also more radical Marxist/Maoist experiments such as the carrying out of productive work in trade schools, the involvement in summer manual work on the part of university students, and the introduction of a student-worker scheme for post-compulsory education students.

In other ways, however, trade schools were closer in spirit to Prosser and Snedden than to Dewey, Marx or Krupskaya. The diluted curricula, untrained teaching staff, the lack of resources, and above all, the setting up of vocational schools as a separate space, all led, as has been shown in other contexts (Sultana 1991b, 1992a), to the provision of not simply a different, but of an inferior kind of education to an overwhelmingly working class student population. The Maltese Communist Party, working with the orthodox Marxist view that a nation had to first go through a capitalist stage in order to develop its industrial base before becoming truly socialist/communist (Vella 1989), agreed with the reforms of the Labour Party, seeing them as "an attempt to 
transform the educational apparatus of the country which has pre-capitalist and pre-industrial roots, into one which meets the needs of Malta's current dependent capitalist development" (Communist Party Electoral Programme 1979: 12). It however correctly pointed out that trade schools ought to give "fundamental importance" to "the study of languages, and social, humanistic and scientific studies". It would be trade schools which would "produce the organic intellectuals of the working class who will be both technicians and political militants, directly involved in the production process and at the same time able to organise the cultural hegemony of their class. After all an illiterate worker will not change any society" (Communist Party Electoral Programme 1979: 12).

But this is precisely what trade schools did not do. As trade schools developed, it became clear that their status as separate institutions rendered them a repository for all that which contradicted the strong discourse of the academic schools. This became especially true when in 1981, selectivity at $11+$ was reintroduced by the Labour Party, and high-status, grammar-type state "junior lyceums" were set up to compete with private schools in the attempt to capture the "brightest and the best". That ideological battle signalled not only the reaffirmation of selectivity, but also the hardening of the distinction between those who were good with their "heads", and those who were good with their "hands". In addition to this, trade schools continued to cater for students from low-income groups. The possibility of privileging manual work, of giving higher status to those involved in manual labour, of linking hand and mind, and of mixing students from different social classes was thus greatly jeopardised.

\section{Do trade schools promote social mixing and equity?}

Comparative education literature proposes three major ideological criticisms of vocational schooling. The first is that these separate schools tend to prepare young people for a narrow range of jobs, so that early on in their lives, vocational students find themselves locked in occupational paths which are usually not highly rewarding. This has in fact led British trade unions to oppose vocational schooling at the secondary school level, since working class students tend to find themselves entrapped and channelled to working class jobs (Jamieson and Lightfoot 1982). In addition to this, the early specialization prevents students in vocational schools from acquiring a sound general education. Finally, trade schools at the secondary education level have been found to lower student aspirations and to encourage the acceptance of a tiered and segmented labour market with differential rewards in the different occupational destinies (Feinberg and Horowitz 1990).

In other words, research has shown that the ideological goals expressed in favour of vocational schooling have often been as difficult to realise as the economic transformation that they were to accompany and, to some extent, lead. As Ralph Dahrendorf pointed out to the Maltese Labour government 
with regards to its educational policies and the student-worker scheme in particular, "others elsewhere in the world have tried such schemes and failed. It produces either unhappy workers or underqualified students, or both. It adds nothing to education or to social integration" (Letter from Prof. Ralph Dahrendorf to the Prime Minister, Dom Mintoff, dated 6/6/78 and written in his capacity as the Government's consultant and advisor on educational reform in Malta).

For these reasons, other European left-wing governments postponed the diversification of education to as late a stage in the student's schooling career as possible. The French Minister of Education between 1981-4, Alain Savary, deferred the choice of students to the trade schools by one year, so that these would be able to spend a longer time in the middle school and have the opportunity to get more general education courses. In addition to this, Savary ensured that there were passarelles, or channels, between the French trade schools and other schools, so that it would be possible for vocational students to switch to the more prestigious Baccalaureat courses and examinations (Dundas-Grant 1985: 259). Similar changes had already taken place in 1977 in Sweden in order to make it possible for vocational-track students to enter University, as well as in most Scandinavian countries where comprehensive education was extended up to the age of 16 in the late 'fifties, and where vocational education was not offered until after school-leaving age (Mjelde 1984).

Most Western social democracies with progressive agendas therefore set out to promote a left-wing ideology, which included a package of educational reforms such as the removal of streaming, comprehensive schooling, and various strategies to ensure equality of opportunity if not of outcome. All this was meant to encourage social class mixing and to enhance the upward social mobility of students from working-class backgrounds. Vocational tracks were either removed or extended to all students, since the traditional dual-stream character of secondary schools worked to reproduce and reinforce occupational stratification through inequalities in educational outcomes.

Again with reference to the Maltese context, trade schools in Malta had to face much the same difficulties in achieving their stated ideological goals as those encountered by other countries, whether these were Western-style social democracies or nations in transition to socialism. Indeed, the very act of setting up vocational schools as a "separate educational space" often serves to set into motion processes which act counter to, and undermine, the most ideologically progressive aims and intentions (Grignon 1971; Oakes 1986; Sultana 1992b). In addition to this, there are two other important aspects which require further exploration. The first refers to the social class composition of the student population in trade schools, the second to the structures of educational opportunity that are available to vocational students as compared to other students in different types of schools. In other words, it will be argued that since (a) vocational students are overwhelmingly from a manual working-class background, and since (b) they have little if any possibility of transferring to another type of school, then the ideological goals of encouraging social class 
mixing, and of facilitating equality of opportunity irrespective of social class background, have in fact been undermined.

The TSRPQ data in fact show that the trade school population is very homogenous. Of the 640 students who gave the required details regarding their father's occupations (33 students gave no details at all; 7 gave insufficient information and therefore could not be classified), as many as 543 - or $84.8 \%$ - had the main bread-winner of the family involved in manual occupations, and various types of skilled, semi-skilled and unskilled manual trades. Only 71 - or $11.1 \%$ - had fathers who were employed in non-manual occupations such as teaching $(n=3)$ and accountancy $(n=3) .410$ students - or $64.1 \%$ had fathers in the two lowest socio-economic sectors established by the 1985 census. While there were 122 - or $19.1 \%$ - who had fathers in the "selfemployed worker" category, 71 of these were in fact involved in skilled or semi-skilled work. The overwhelmingly working-class origins of trade school students becomes even more evident when one keeps in mind that the data just presented refer to students at school during the survey period. $42.5 \%$ of students were absent and, given that absenteeism and early school-leaving are closely correlated to class, the total percentage of working-class students is even higher than intimated above. In addition to this, the TSRPQ also collected information regarding the students' mothers' occupation, before and/or after marriage (Malta has the lowest female participation rate in the labour market in Europe. This stood at $26 \%$ in 1988 , compared to $61 \%$ in EFTA countries and $49 \%$ in the EEC, cf. Galea 1988). Of the 276 who worked before marriage, 106 - or $38.4 \%$ - were factory workers and 89 - or $32.2 \%$ - were maids. Similarly, of the 52 women who worked following their marriage, 20 - or $38.5 \%$ - were maids, and 10 - or $19.2 \%$ - were factory workers. In all, therefore, $87.7 \%$ of all mothers of trade school students who worked before marriage were involved in manual labour.

Data were also collected regarding the occupations of siblings of students attending the vocational schools. This information is important not only because it confirms the working-class extraction of a particular individual, but because it addresses the question of inter-generational mobility. Out of a total of 438 siblings whose occupations were reported in the TSRPQ, 315 (or $71.9 \% \%$ ) held manual jobs. Of these, 118 were labourers and factory workers, and 87 were doing the kind of skilled and semi-skilled trades and crafts that their brothers and sisters were learning in trade schools. Only 9 siblings were reported holding occupations in the first two categories in the socio-economic sectors established in the 1985 Census.

The homogeneity of class extraction not only means that there is little social class mixing going on in trade schools, but also that students tend to bring with them the same anti-academic orientation, typical of working-class culture, which militates against the creative resolution between the dichotomy of "hand" and "mind" (Willis 1977). The lack of legitimacy of schooling was reflected in the fact that as many as 335 out of the 680 students - or $52.2 \%$ - did not know the extent of their father's schooling, while 316 - or $46.5 \%$ 
- were quite unaware of how long their mother had spent at school. Out of those who did know their parents' educational career, one can notice a pattern of both parents leaving school at primary level, before finishing secondary school, or on finishing fifth form at the secondary school level.

Only seven parents of trade-school students had gone on to sixth form, while three had gone to Teachers' College, and two to University. In addition to this, vocational students were asked to give information regarding the educational paths followed by their siblings. There were 316 responses which gave information about brothers, and 255 about sisters. 132 - or $41.8 \%$ - of the brothers and $60-23.5 \%$ - of sisters had in fact attended trade schools before going on to a job, and this indicates a tendency for the reproduction of both occupational (manual) and educational (vocational) experiences in the same family (Surprisingly, trade school students reported that 31 male siblings and 40 female siblings only had primary schooling). There is also a low participation rate on the part of male and female siblings in academic-type schools, with 20 male and 31 female siblings having attended junior lyceums, and 9 male and 6 female siblings having attended private schools. There were also low participation rates in post-secondary educational establishments, be these sixth form (male $=14$, female $=19$ ), technical institutes (14 and 1 , respectively), or University (10 and 6, respectively).

The lack of social mixing and the inequitable opportunities offered in trade schools is reinforced by the fact that the strong classification between segments of the Maltese educational structure serves to intensify class and gender segregation and differential achievement. While students have, in theory, some possibility of moving from one part of the educational system to another - such as opting for or out of private schools, or for or out of state grammar lyceums - the general tendency is for students to remain in the school types they start in. In the case of trade schools the demarcation lines are even more definite, as, given a different and diluted curriculum, it is extremely difficult and unlikely for a trade school student to transfer to an "academic" type of school, and practically impossible - unless he or she takes private tuition - to go to university. In other words, there are few effective passarelles - or ways out of a trade school.

The most obvious repercussion of the lack of social class mixing is that vocational students tend to bring to school a personal and family history of lack of investment and of achievement at school, which in turn tends to limit their horizons by reinforcing many of the views they bring with them to the school. This confirms for the students "their view of themselves as working to lower class and as uninterested in and resistant to academic instruction" (Claus 1990: 22). This does not necessarily mean that parents of trade school students are uninterested in the education of their children, or that they do not have cultural resources which are valuable and useful. However, the fact that only about $30 \%$ of the parents turned up at parents' day meetings was, to teachers, just one example of the lack of commitment towards education. But responses to the TSRPQ accord with empirical research carried out both 
locally (Farrugia 1992) and overseas (Branthlinger 1985). These suggest an alternative explanation and help dispel the myth that working-class parents are not interested in their children's schooling. The following is a break-down of the educational support parents offered to their boys and girls attending the third year of a trade school course:

\begin{tabular}{lll} 
Parents & Male students & Female students \\
\hline Urge you to read & 305 or $62.3 \%$ & 127 or $65.6 \%$ \\
Buy you tools & 329 or $67.6 \%$ & 156 or $80.4 \%$ \\
Ask about school & 291 or $59.9 \%$ & 100 or $51.6 \%$ \\
Discuss your future & 367 or $75.5 \%$ & 151 or $77.1 \%$ \\
Help in theory of trade & 138 or $28.4 \%$ & 78 or $40.2 \%$ \\
Help in practice of trade & 225 or $46.3 \%$ & 126 or $64.9 \%$
\end{tabular}

These parents do believe in the value of education, though they are likely to be sceptical about how it will actually benefit their children. In other words while "schools may have minimal expectations from low-income pupils .. . low-income people appear to have minimal expectations for schools" (Brantlinger 1985: 26). They also tend to have restricted knowledge of the way the school system works, and the implications that schools' processes, like inter- and intra-school streaming, have for their children's futures (Gatt and Vassallo Agius 1988), and find themselves lacking the cultural resources which are valuable for acting on schools and for complying with the school's requests (Lareau 1987). The distance that exists between all Maltese schools and the community merely reinforces the tendency for working-class parents to be "frozen out" of schools (Connell et al. 1982). In addition, workingclass parents are more likely to believe in advancement through on-the-job training and through opportunities offered within employment, rather than through schools and credentialling.

\section{Conclusion}

Clearly, then, trade schools in Malta have not been very successful in achieving the ideological goals that were set out for them, for they have generally failed to conscientize and serve the interests of their clientele, if those interests are understood as being the progressive self-determination of that group. Trade schools have also failed to either give a high status to the manual, or to link the hand and mind. Finally, rather than social mixing, trade schools have gathered together a homogenous group of students who come from similar socio-cultural backgrounds. This has jeopardised both ideological and related educational goals. This study therefore confirms the evaluations of vocational schools carried out in other contexts, and serves as a timely reminder, in the age of a "new" vocationalism (Bates et al. 1984), that irrespective of the good intentions behind any reform which sets out to 
provide "relevant" schooling, the results will very likely be the same as in Malta: namely, the creation of lower-status tracks and/or schools for low-status students who will be offered an inferior, diluted form of education which will lead to the reproduction of social inequalities from one generation to the next. As Bernstein noted when referring to moves to include technical elements and a "relevant" curriculum in British schools, such innovations are often "not simply for the transmission of educational knowledge, but for the purposes of social control of forms of deviancy, and that usually occurs with the "less able" children whom the school has given up educating" (1971: 58).

This case study, I would argue, has implications beyond the field of education. Socialist voices are clearly attempting to re-emerge "after the fall" (Blackburn 1991) in the post-1989 world. It is crucial that those of us who think that that tradition still has a future (Habermas 1990; Bottomore 1992), look squarely into the face of the past to dream and struggle for a future where concerns with equity and social justice rather than with a stale technocratic rationality prevail. Analyses such as the present one can, from a concern with substantive investigations in a particular field, lead to a more sophisticated and formal theoretical understanding of the limitations of what can be referred to as "utopian urges". This not only leads us to the key dilemma at the heart of sociology, namely the relationship between structure and agency, but to that strategic question which still rings vibrantly today, namely: "What is to be done?"

\section{Acknowledgement}

The analysis in the article is inspired by the agenda set by Carnoy and Samoff (1990) in their analysis of education and social transition in the third world. I am particularly indebted to Martin Carnoy who discussed with me some of the ideas expressed in this article when I was a Fulbright Visiting Scholar at Stanford University in 1990.

\section{Notes}

1. Three tracer studies were carried out with two groups of students. The first group consisted of students who left their trade school before the completion of their third year in 1987/88 (Vella 1992; Bianchi 1992); the second group was made up of those who had left after the completion of their third year in 1987/88 (Chetcuti 1992).

2. The research team was made up of graduate and undergraduate students from the sociology of educational development at the University of Malta. Their contribution to the overall research project is acknowledged in various places throughout this paper. All research tools were designed by the present author, and the qualitative dimension of the study is based on the grounded theory approach pioneered by Glaser and Strauss (1967). 
3. Three newspapers are referred to in this article. The Sunday Times of Malta and the Times of Malta are "independent" newspapers, sympathetic to business and Nationalist Party interests. L-Orizzont (or "The Horizon") is the official paper of the General Workers' Union, faithfully reflecting Labour Party views. Excerpts quoted from the latter have been translated by the author.

4. Much of the language of politicians in the 'seventies is steeped in sexism. I point this out in lieu of punctuating quotations with [sic] after every "he", "him", or "man".

5. The setting up of trade schools was motivated by other reasons. These have been explored in detail in another context (Sultana 1992a); it is sufficient here to note that the Labour government hoped that a more hands-on approach to leaming would make the extension of compulsory schooling by two years - an obvious temptation in the face of high unemployment - more palatable to reluctant students. In addition, the government hoped that this different form of schooling would remotivate those students who had experienced failure in the traditional education system.

6. This study involved interviews with 80 students and 25 teachers, and 240 hours of classroom observation in two trade schools and two academic schools (in all, two boys' schools and two girls' schools).

7. In this study, 41 students and 12 teachers were interviewed, and 65 hours of classroom observation were carried out.

\section{References}

Anyon J. 1981. Social Class and the Hidden Curriculum of Work. Journal of Education 162.

Apple, M.W. 1990. Ideology and Curriculum 2e. New York: Routledge.

Azzopardi, N. and Bondin, A. 1991. Resistance to Schooling. Unpublished B.Ed. (Hons.) dissertation. University of Malta.

Balogh, T. and Seers, D. 1955. The Economic Problems of Malta: An Interim Report. Malta: Government Printing Office.

Bates, I. et al. 1984. Schooling for the Dole: The New Vocationalism. Houdnmills: Macmillan.

Benavot, A. 1983. The Rise and Decline of Vocational Schooling. Sociology of Education 56.

Bernstein, B. 1971. On the Classification and Framing of Knowledge. In: M.F.D. Young, ed., Knowledge and Control. London: Macmillan.

Bianchi, A. 1992. Trade School Tracer Study: Early Leavers. Diploma in Educational Administration and Management dissertation. University of Malta.

Blackburn, R., ed. 1991. After the Fall: The Failure of Communism and the Future of Socialism. London: Verso.

Bottomore, T., ed. 1992. Socialism of the Future: A Journal of Political Debate. London: Pluto Press.

Bowles, S. and Gintis, H. 1976. Schooling in Capitalist America. New York: Basic Books.

Bowles, S. and Gintis, H. 1981. Contradictions and Reproduction in Educational 
Theory. In: R. Dale et al., eds., Education and the State: Schooling and the National Interest. Lewes: Falmer.

Bowles, S. and Gintis, H. 1988. Reply to our Critics. In: M. Cole, ed., Bowles and Gintis Revisited. Lewes: Falmer.

Brantlinger, E. 1985. What Low-income Parents Want from Schools: A Different View of Aspirations. Interchange 16(4).

Briguglio, L. 1988. The Maltese Economy: A Macro Economic Analysis. Malta: David Moore Holdings Ltd.

Carnoy, M. 1990. Education and the Transition State. In: M. Carnoy and J. Samoff, eds., Education and Social Transition in the Third World. Princeton: Princeton University Press.

Carnoy, M. and Levin, H. 1985. Schooling and Work in the Democratic State. Stanford: Stanford University Press.

Chetcuti, H. 1992. Trade School Tracer Study - Course Completers. Diploma in Guidance and Counselling dissertation. University of Malta.

Claus, J. 1990. Opportunity or Inequality in Vocational Education? A Qualitative Investigation. Curriculum Inquiry 20(1).

Communist Party. 1979. Electoral Programme. Malta: Mimeo.

Connell, R.W., Ashendon, D.J., Kessler, S. and Dowsett, G.W. 1982. Making the Difference: Schools, Families and Social Division. Sydney: Allen \& Unwin.

Corbon, C.A. 1859. De L'Enseignement Professionel. Paris: Imprimerie de Dubuisson.

Da Silva, T. 1988. Distribution of School Knowledge and Social Reproduction in a Brazilian Urban Setting. British Journal of Sociology of Education 9(1).

Darmanin, M. 1992. The Labour Market of Schooling: Maltese Girls in Education and Economic Planning. Gender and Education 4(1).

Department of Information. 1974. Constitution of the Republic of Malta. Malta: Government Printer.

Dewey, J. 1915. Education vs. Training. New Republic May 1915, as reproduced in Curriculum Inquiry 7(1), 1977.

Dundas-Grant, V. 1985. The Organisation of Vocational-Technical-Technological Education in France. Comparative Education 21(3).

Farrugia, J. 1979. Occupational Categories and Wages in Malta. Unpublished B.A. dissertation. University of Malta.

Farrugia, S.R. 1992. Attitudes to Schooling by Working-Class Parents: An Empirical Analysis. Unpublished B.Ed. (Hons.) dissertation. University of Malta.

Feinberg, W. and Horowitz, B. 1990. Vocational Education and Equality of Opportunity. Journal of Curriculum Studies 22(2).

Freire, P. 1972. Pedagogy of the Oppressed. Middlesex: Penguin.

Galea, L. 1988. Address Reported in CIMIRA. Malta's Changing Labour Market. Malta: Mimeo.

Gatt, C. and Vassallo Agius, S. 1988. A Study of the Knowledge and Attitudes that Primary Pupils Have of Streaming. Unpublished B.Ed. (Hons.) dissertation. University of Malta. 
Glasser, B.G. and Strauss, A.L. 1967. The Discovery of Grounded Theory: Strategies for Qualitative Research. Chicago: Aldine.

Graduate Teachers' Association of Malta. 1970. Report on Secondary Education for All. Malta: Mimeo.

Grignon, C. 1971. L'Ordre des Choses. Paris: Editions de Minuit.

Guidance and Counselling Services. 1990. Results of a Tracer Study Held in October/November 1990. Malta: Education Department, Mimeo.

Habermas, J. 1990. What Does Socialism Mean Today? The Rectifying Revolution and the Need for New Thinking on the Left. New Left Review September/October.

Jamieson, I. and Lightfoot, M. 1982. Schools and Industry. London: Methuen.

Kantor, H. 1986. Work, Education and Vocational Reform: The Ideological Origins of Vocational Education, 1890-1920. American Journal of Education 94(4).

Krupskaya, H. 1985. On Labour Oriented Instruction and Education. Moscow: Progress Publishers.

Lareau, A. 1987. Social Class Differences in Family-School Relationships: The Importance of Cultural Capital. Sociology of Education 60.

Marx, K. 1967. Capital Vol. 1. New York: International Publishers.

Mifsud, M.J. and Mallia, M. 1991. School Bells and Punchclocks: The Ideology of Work in Maltese Schools. Unpublished B.Ed. (Hons.) dissertation. University of Malta.

Mjelde, L. 1984. Between Schooling and Work: Women and Vocational Training in Norway. Resources for Feminist Teaching 13(1).

Mjelde, L. 1987. Labour and Learning: Apprenticeship in Transition from the Medieval Guilds to the 1980s (Mimeo).

Morrison, K. 1989. Bringing Progressivism into a Critical Theory of Education. British Journal of Sociology of Education 10(1).

Ornelas, C. 1981. The Producer Co-operatives of Mondragon and the Combination of Study with Productive Labour. Education with Production 1(1).

Oakes, J. 1986. Beyond Tinkering: Reconstructing Vocational Education. In: G.H. Copa, J. Plihal and M.A. Johnson, eds., Re-visioning Vocational Education in the Secondary School. Minnesota: Minnesota Research and Development Center for Vocational Education.

Office of the Prime Minister. 1973. Outline of a Development Plan for Malta, 1973-1980. Malta: Government Printer.

Price, R. 1977. Marx and Education in Russia and China. London: Croom Helm.

Psacharopoulos, G. 1987. To Vocationalize or Not to Vocationalize: That Is the Curriculum Question. International Review of Education 33(2).

Shilling, C. 1989. Schooling for Work in Capitalist Britain. Lewes: Falmer.

Simon, R., Dippo, D. and A. Schenke. 1991. Learning Work: A Critical Pedagogy of Work Education. Ontario: OISE Press.

Sultana, R.G. 1989. Transition Education, Student Contestation and the Production of Meaning: Possibilities and Limitations of Resistance Theories. British Journal of Sociology of Education 10(3). 
Sultana, R.G. 1990. Schooling for Work in New Zealand. British Journal of Education and Work 3(3).

Sultana, R.G. 1991a. Social Movements and the Transformation of Teachers' Work: Case Studies from New Zealand. Research Papers in Education 6(2).

Sultana, R.G. 1991b. Social Class and Educational Achievement in Malta. In: R.G. Sultana, ed., Themes in Education: A Maltese Reader. Malta: Mireva Publications.

Sultana, R.G. 1992a. Vocational Schools and the Structuring of Inequality. In: T.J. Plomp, J.M. Pieters and A. Feteris, eds., European Conference on Educational Research Vol. 3. Enschede: University of Twente.

Sultana, R.G. 1992b. Education and National Development: Historical and Critical Perspectives on Vocational Schooling in Malta. Malta: Mireva.

Sultana, R.G. 1993. Vocational Schooling and Economic Development: A Maltese Case Study. International Journal of Educational Development 14(1).

Tse Tung, M. 1964. On Practice: On the Relation between Knowledge and Practice, between Knowing and Doing. Selected Works Vol. I. Peking: Foreign Language Press.

Vella, F. 1992. Trade School Tracer Study: Early Leavers. Unpublished Diploma in Guidance and Counselling dissertation. University of Malta.

Vella, M. 1989. Reflections in a Canvas Bag: Beginning Philosophy between Politics and History. Malta: PEG.

Watkins, P.E. 1980. Curriculum Change and the School-Work Interface: A Critical Analysis of Work Experience. Australia and New Zealand Journal of Sociology 16(2).

Willis, P. 1977. Learning to Labour. Farnborough: Saxon House.

Wirth, A.G. 1988. Issues in the Vocational-Liberal Studies Controversy - 1900-1917: John Dewey and the Social Efficiency Philosophers. In: D. Corson, ed., Education for Work: Background to Policy and Curriculum. Palmerston North: Dunmore Press.

Zahra, S. and Ebejer, E. 1992. The Wants and Needs of Industry: An Educational Perspective. Unpublished B.Ed. (Hons.) dissertation. University of Malta.

Zammit, E.L. 1984. A Colonial Inheritance: Maltese Perceptions of Work, Power and Class Structure with reference to the Labour Movement. Malta: University of Malta. 